\title{
How Korean K-12 Educators Adapted to Online Teaching and Promoted Digital Equity During COVID-19: A Mixed-Method Study on Practices and Perceptions
}

\author{
Eunhye Grace $\mathrm{Ko}^{1}$, Soo Hyoung $\mathrm{Joo}^{2}$, Kyu Yun $\mathrm{Lim}^{3}$, Paul E. Resta ${ }^{4}$, Eun Kyoung Jang ${ }^{5}$ \\ ${ }^{1}$ The University of Texas at Austin, USA. Email: eko@utexas.edu \\ ${ }^{2}$ Teachers College, Columbia University, South Korea. Email: shj2118@tc.columbia.edu \\ ${ }^{3}$ Seoul Metropolitan Office of Education, Canada. Email: kyuyun.lim@alumni.ubc.ca \\ ${ }^{4}$ The University of Texas at Austin, USA. Email: resta@austin.utexas.edu \\ ${ }^{5}$ Eun Kyoung Jang, Korea. Email: sagac98@garak.sen.hs.kr \\ Correspondence: Eunhye Grace Ko, The University of Texas at Austin, USA. Email: eko@utexas.edu
}

Received: November 7, 2021

doi:10.11114/jets.v10i1.5422

\author{
Accepted: December 8, 2021 \\ Online Published: December 12, 2021 \\ URL: https://doi.org/10.11114/jets.v10i1.5422
}

\begin{abstract}
The abrupt transitions to online teaching during COVID-19 have exacerbated educational discrepancies worldwide. South Korean schools faced similar challenges primarily due to the insufficient infrastructure and pedagogical guidelines for online teaching. This mixed-method case study investigated how Korean K-12 teachers and administrators converted to online teaching and addressed related digital equity issues during their first semester of online teaching in response to the pandemic. Interviews, as well as survey responses at the beginning and end of the semester, were analyzed through Activity Theory (AT) and Technological Pedagogical Content Knowledge (TPACK) frameworks. The study's key insights were that the digital equity issue is related to quality teaching issues beyond infrastructural problems and that teachers took various strategies to maximize the effectiveness of their blended teaching. We aim to shed light on supporting equitable online learning and sustaining positive changes in the post-COVID era.
\end{abstract}

Keywords: activity theory, blended and online teaching, COVID-19, digital equity, mixed-method, TPACK

\section{Introduction}

The unexpected school closures during the COVID-19 crisis exacerbated educational discrepancies worldwide, significantly affecting underprivileged students who lack technological, educational, and parental support for online and blended learning (Masonbrink \& Hurley, 2020). South Korean K-12 schools have also converted to online teaching in April 2020 and faced similar challenges, primarily due to the lack of infrastructure and pedagogical guidelines for online teaching during the unanticipated transition (Choi, 2020; Kwon, 2020). For instance, at the beginning of the outbreak, many public schools in underfunded districts lacked digital devices and networks to support online learning (Choi, 2020). Although 70 percent of Korean households had Internet access, some still faced problems sharing devices with their siblings (Lee, 2020).

As the COVID-19 cases started to drop, Korean K-12 schools partially reopened in June 2020, being forced to transition to a blended teaching model, where students attend remote and on-campus classes alternatively every other week. Although this model is expected to last until the end of the outbreak, the transition again was abrupt and did not allow teachers to prepare for the unique challenges of blended teaching. As the anecdotal evidence in numerous news reports showed, teachers struggled to adapt to these tumultuous changes. On an infrastructural level, for example, teachers expressed difficulties recording online lessons in classrooms that lacked wireless internet access, and many had to purchase software for content creation out of their pockets because an edtech product procurement system was not established (Son et al., 2020). On a pedagogical level, some teachers could only provide links to educational videos created by the government due to their lack of digital literacy, which disengaged students, especially those who lacked motivation and parental support (Yoo, 2020).

While these observations illustrate various sources of digital inequity, a systematic investigation on how the administrators 
and teachers perceived these challenges and addressed them in the Korean K-12 context has not yet been conducted to the best of our knowledge. By focusing on the administrators' and teachers' perspectives on the infrastructural, pedagogical, and parental factors related to online and blended teaching, we can holistically understand how to support teachers who struggle to promote equitable learning through various teaching methods. Also, it is necessary to follow the perception changes longitudinally, from the beginning of the outbreak when teachers first transitioned to online teaching to when the blended teaching format was adopted, as the in-person classes were gradually allowed. The longitudinal insights could inform whether these changes can extend to the post-COVID era when teachers will no longer be required to adopt online or blended teaching.

\section{Objectives and Purposes}

This study aims to understand and record how the South Korean K-12 administrators and teachers converted to online teaching and addressed related digital equity problems. In this research, digital equity refers to securing equal access to technology for all students and the training necessary to navigate digital tools (Pullias Center for Higher Education, n.d.). Furthermore, it probes teachers' perspectives on how different online teaching methods may have influenced the students' learning experience. This study extends recent scholarship on digital equity (Resta \& Laferrière, 2015; Solomon, 2002) as well as online and blended teaching (Stein \& Graham, 2020; Christensen et al., 2013) by researching teachers and administrators' practices during the pandemic focusing on the Korean K-12 context as a case study. This study can provide shared insight on the development of online teaching practices to address digital equity problems.

On this account, this mixed-methods study designed with pragmatics epistemology involved two surveys and ten interviews following the trajectory of the first semester of online teaching in response to the COVID-19 outbreak. To understand the teachers' and administrators' readiness before the transition to online teaching and practices throughout their first semester, the study investigates the following questions:

1. During the first 6-months of online teaching in response to the COVID-19 outbreak, what were the digital equity problems Korean K-12 teachers and/or administrators faced, and how did they address them?

2. During the first 6-months of online teaching in response to the COVID-19 outbreak, how did they convert to online teaching?

a. What online teaching methods (i.e., task-type, content-type, interactive-type) did they choose, and what factors impacted their choice?

b. How did their online teaching pedagogies evolve?

c. What are the perceived impacts of online teaching experience on future teaching and professional development?

\section{Theoretical Framework}

This study employs pragmatism to deal with practical, multidimensional, and timely problems of blended teaching during the pandemic (Tashakkori \& Teddlie, 2009). By adopting this perspective, the study connects valid points between the survey and interview data to answer research questions (Mertens, 2015). Accordingly, the study intends to investigate the multidimensional aspects of teaching during COVID-19: teaching practices and their development; pedagogical intentions and choices; policies and teaching environments; and digital equity problems and potential solutions.

Teaching during the pandemic is complex as it not only involves the classroom environment but is strongly tied to family support, digital equity, teacher communities, school culture, district office support, and educational and social policies. To capture these aspects, this study selected activity theory (AT; Engeström, 1999) as the theoretical framework. AT is a philosophical framework for investigating human praxis in individual and social levels interlinked simultaneously (Kuutti, 1996). It focuses on the interaction of human activity within its relevant environmental context (Jonassen \& RohrerMurphy, 1999). In analyzing human activity, the following factors are examined (as shown in Figure 1): types of activities humans are engaged in, subjects engaging in that activity, objectives and outcomes, results from the activity, rules applied, tools used, and the community in which the activity occurs (Jonassen \& Rohrer-Murphy, 1999). In this study, Korean K12 teachers are considered as subjects of the activity where equitable, and equitable, and effective online teaching is the object. Environmental factors such as national, district, or school policies are considered rules, and teacher-parent relationships, teacher communities, and school culture are considered community factors. Furthermore, digital equity factors, including the teaching environment and resources or students' learning environments, are considered tools. Lastly, the division of labor within a school or district is examined. 


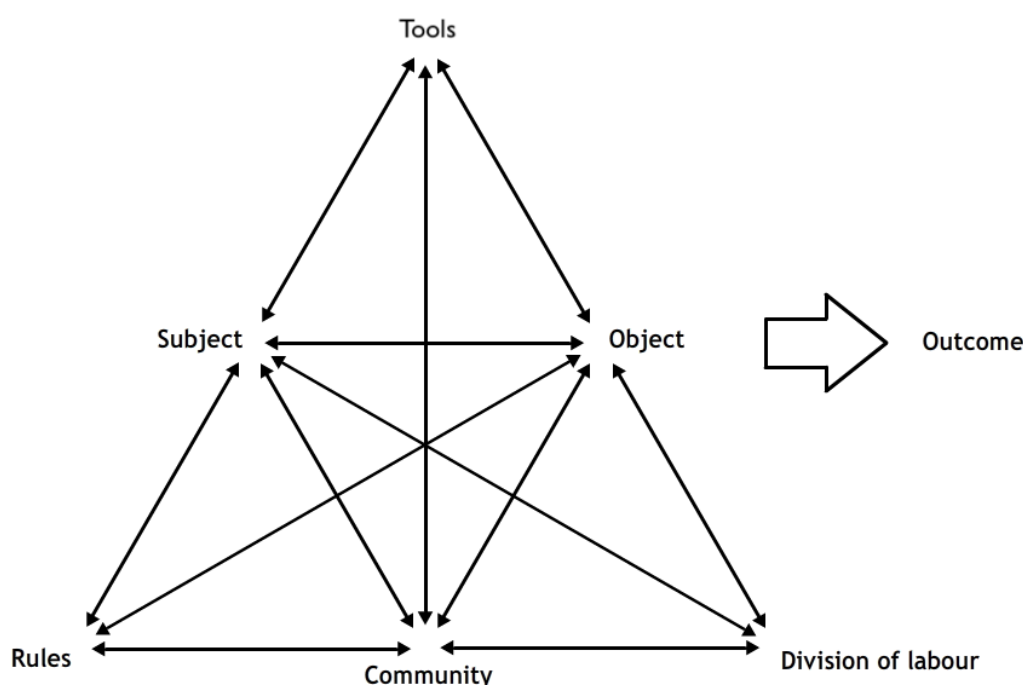

Figure 1. Engeström's Model of Activity (Bury, 2012)

In addition to AT as a theoretical framework, this research adopted Technological Pedagogical Content Knowledge (TPACK) as a conceptual framework because it provides a set of knowledge teachers need to teach effectively with technology. (Koehler \& Mishra, 2009). The TPACK framework was applied to create questions for understanding teachers' use of technology in blended learning design and evaluate the impact of the blended teaching experience (Tanak, 2018). Koehler and Mishra (2009) define TPACK as an integration of technological, pedagogical, and content knowledge in which the interactions between these components constitute variations in knowledge. The variations include technological knowledge (TK), pedagogical knowledge (PK), content knowledge (CK), technological pedagogical knowledge (TPK), technological content knowledge (TCK), pedagogical content knowledge (PCK), and TPACK. While TPACK includes seven areas of knowledge, this research focuses on four TPACK constructs involving technology: TK, TPK, TCK, and TPACK because the use of technology is a core component of online teaching.

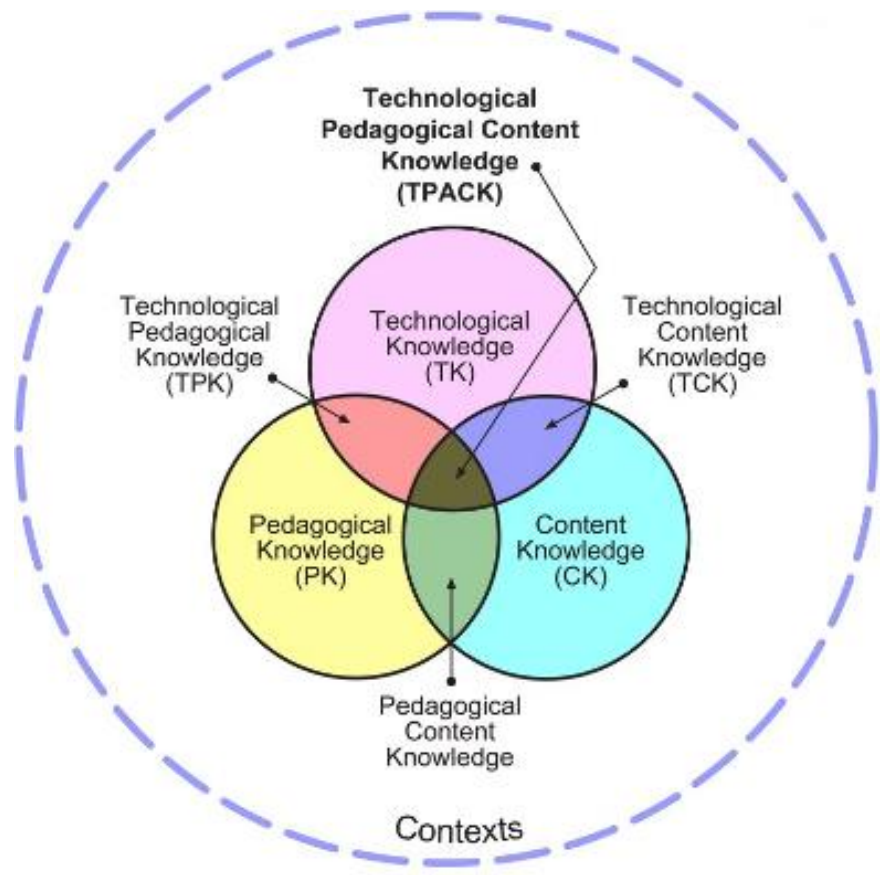

Figure 2. TPACK framework (TPACK.ORG, 2012)

\section{Literature Review}

\subsection{Korean Online and Blended Education Prior to COVID}

In order to situate our study in the broader context of K-12 online education, we reviewed the literature on South Korean $\mathrm{K}-12$ online education prior to COVID with a focus on public platforms and government policies.

For individuals, the Korean government created an Educational Broadcasting Station (EBS) in 1990 to provide 
educational TV programs to supplement school education and encourage lifelong learning (EBS, 2021). In 2004, EBS started providing an online learning platform that served as Korea's largest public e-learning provider (Teo et al., 2020). The online learning platform has accumulated and provided online learning videos for every K-12 subject without a charge for the past 30 years. Before COVID-19, Yoon and Kim's (2016) study showed that the platform has been serving as an equalizer for Korean public education through its easy access and extensive curriculums. They compared the students' school achievement test scores of those who did and did not participate in EBS online learning using logistic regression, and found that those who watched the EBS videos performed better in school by $5.04 \%$. As the platform readily incorporated videos for the K-12 curriculum, the Korean government rapidly transitioned the EBS contents to a new learning management platform tailored to blended public education during the pandemic (EBS Online Class, 2021). Although the rapid transition and extensive video curriculum were critical for addressing educational emergencies, teachers indicated various problems such as inefficient user interface, lack of teacher-student interaction, and server capacities (Kwon, 2021).

At school level, distance education for K-12 was set as one of the main agendas by the Ministry of Education in 2011 to secure the students' right to learn and mitigate the imbalance of learning opportunities (Chung et al., 2018). For instance, online courses were provided for students who wished to study rare elective courses that were difficult to operate in unit schools or were not offered due to the lack of resources at small-sized rural schools. Additionally, online courses supplemented learning for students who could not complete courses due to transfer or long-term illness and hospitalization. Several centralized online course platforms offered online course contents, while individual schools and district offices administered attendance, assessment, and grade reporting in a blended format (Chung et al., 2018). As each platform served different purposes and provided varying contents, they implemented different methodologies of conducting online classes; some offered video-content-based lectures, and some offered synchronous classes (Son et al., 2019). As of 2017, about $35 \%$ of Korean high schools reported to have provided their students with online course options as a part of their school curriculum; however, only $0.4 \%$ of the high school students reported to have experienced online courses as part of the school curriculum (Lee et al., 2017). Although the Korean Ministry of Education has provided a range of online education policies and programs far before the COVID-19, they were limited to electives or afterschool courses, or outof-school adolescents; therefore, school-wide implementation of online education was new to most K-12 teachers and students during the COVID-19.

\subsection{Online and Blended Teaching During COVID}

Due to the pandemic's recency, literature probing the impact of COVID-19 on K-12 education is relatively scarce. ButlerHenderson et al. (2020) have created a literature database, CHELD V1, for aggregating studies on COVID-19's impact on higher education. As of June 2020, they found 138 studies and analyzed the studies' qualities, methods, and research emphases. Only 58 studies were medium to high quality, and most studies focused on the early stages of pandemic response - rapid adaptation and improvement strategies. Of these studies, 33 were theoretical, 18 qualitative, three quantitative, and four mixed-methods studies. This analysis shows the need for additional mixed-methods empirical studies that deeply investigate COVID-19's impact on K-12 education.

Despite the exigency of the issue, empirical studies investigating COVID-19's impact on K-12 online education are scarce in peer-reviewed academic journals. Among the few studies identified, Korkmaz and Toraman (2020) analyzed Turkish K-12 educators' perceptions $(n=654)$ on educational practice during COVID-19. The study showed that $60 \%$ of K-12 educators experienced students' internet connection problems, and 56\% of K-12 teachers encountered online learning management systems' user interface issues. In providing feedback to students during online lessons, $77 \%$ of the K-12 teachers reported problems. Also, $48 \%$ of the teachers did not have a suitable environment at home for online teaching. Korkmaz and Toraman's (2020) study showed how Turkish K-12 educators faced pedagogical and infrastructure issues.

Some researchers explored the transitions to online teaching and digital equity by examining the lived experiences of K12 teachers. Kaden (2020) investigated how a single K-12 teacher adapted to the COVID-19 school closure and conducted lessons in Alaska, USA. The study demonstrated that online education could support learning for many students; however, it needs to be carefully designed and individualized not to deepen digital and social divides. Furthermore, Kaden (2020) concluded that the forced move to online learning could catalyze effective hybrid learning models and equitable educational opportunities.

Vu, Meyer, and Taubenheim (2020) similarly researched an individual Kindergarten teacher's lived experience. The teacher supported her students to achieve quality online learning at home. Before the transition, the administration took timely responses to communicate with parents to ensure infrastructure. Thus, the teacher could adopt various entertaining activities both synchronously and asynchronously. As a result, students' high-quality work and parents' satisfaction were reported. The authors emphasized two main factors of successful online learning: (a) teachers' creativity in designing diverse, fun activities and (b) timely communication among school administrators, teachers, parents, and students. 
The Korean Education and Research Information Service (KERIS) (Kye et al., 2020) surveyed 51,021 teachers and 212,434 middle and high school students to understand the first 6-month of the online learning experience. Among students, $68 \%$ thought online education was effective, and 56\% thought online learning contributed to developing selfdirected learning abilities. The report indicated that $32 \%$ of the students who answered online education to be ineffective might be at the risk of learning loss, and $37 \%$ of teachers said the learning gap could be addressed via offline education once blended learning starts. Among teachers, $40 \%$ viewed online education positively as they believed it provided continuous education, $28 \%$ thought online learning contributed to flexibility, and $10 \%$ believed students increased selfdirected learning skills. Regarding whether they wished to continue blended teaching post-Covid, $54 \%$ of teachers showed willingness. Teachers also thought that online teaching experience contributed to developing innovative teaching methods (56\%), teacher collaboration ( $8 \%)$, and teaching competency (6\%).

Although there are several qualitative case studies of single K-12 teachers' online teaching experiences and governmentled survey data, not many studies have been conducted with a group of teachers using a mixed-method approach. Furthermore, few studies have investigated underlying factors influencing pedagogical decisions or longitudinal approaches to teachers' online teaching evolution. To holistically understand multifaceted aspects of teaching during the pandemic, we need to explore beyond individual experience and investigate systemic issues such as administrative support, digital equity, teacher communities, school culture, district office support, and educational and social policies. In this case study of Korean educators, we aim to provide an in-depth understanding of factors influencing pedagogical decisions and actual teaching practices, which can serve as a starting point for investigating the transition to online learning on a global scale.

\section{Methodology}

Because our research questions involve multiple aspects of teaching during COVID-19, such as pedagogy, digital equity, policies, and school culture, this concurrent triangulation mixed study draws data from qualitative and quantitative methods to provide complementary data on the same aspects (Creswell \& Plano Clark, 2007). The mixed-method approach was taken to operationalize AT and TPACK by coding the qualitative data and using the quantitative data to expand and validate the qualitative data (McAvina, 2016). More specifically, the study converges two surveys and interviews, collected concurrently within 6-months of the COVID-19 outbreak. The surveys and interviews were analyzed independently and triangulated to address the research questions. We expected that the data from different sources might corroborate, complement, or contradict each other, considering the complexity of blended teaching during this challenging time (Caffery et al., 2019).

Both survey and interview questions related to the teaching methods were designed based on the Korean Ministry of Education's online teaching guideline (KMoE, 2020a). The guideline suggested the three methods of online learning: (a) one-way task-oriented lesson, which assigns quizzes or self-directed tasks asynchronously (task-type, henceforth); (b) one-way content-oriented lesson, which uses teachers-created lectures or external resources to deliver the lesson contents asynchronously (content-type, henceforth); and (c) real-time interactive lesson through which a teacher and students interact synchronously via video-conferencing tools (interactive-type, henceforth). According to Moore's Theory of Transactional Distance (Moore, 1997), the relationship between instructor and student in online learning is the most distant in one-way task-oriented lessons and closest in real-time interactive lessons.

\subsection{Participants}

The study participants include approximately 150 K-12 school teachers in South Korea, teaching various subjects across the country, and five district administrators, as shown in Table 1. As the study aimed to do a trend analysis, the survey was distributed through various online teacher communities, and a convenient sampling method was used. Thus, it included the same general population but not the same individuals in the readiness and reflection surveys (Mertens, 2015). The interviewees were selected among the volunteers from the online teaching reflection survey. 
Table 1. Participant demographics

\begin{tabular}{|c|c|c|c|c|c|}
\hline & & \multirow{2}{*}{$\begin{array}{l}\text { Online teaching } \\
\text { readiness survey } \\
\quad(\mathrm{n}=145)\end{array}$} & \multicolumn{2}{|c|}{$\begin{array}{l}\text { Online teaching } \\
\text { reflection survey }\end{array}$} & \multirow{2}{*}{$\begin{array}{l}\text { Interviews } \\
\text { Teachers } \\
(n=10)\end{array}$} \\
\hline & & & $\begin{array}{l}\text { Teachers } \\
(\mathrm{n}=137)\end{array}$ & $\begin{array}{l}\text { Administrators } \\
\qquad(\mathrm{n}=5)\end{array}$ & \\
\hline \multirow[t]{2}{*}{ Gender } & $\mathrm{F}$ & $96(66 \%)$ & $86(68 \%)$ & $2(40 \%)$ & 8 \\
\hline & M & $49(34 \%)$ & $40(32 \%)$ & $3(60 \%)$ & 2 \\
\hline \multirow[t]{7}{*}{ Experience } & Less than 5 years & $21(14 \%)$ & $21(17 \%)$ & & 1 \\
\hline & $5-10$ & $22(15 \%)$ & $27(21 \%)$ & & 2 \\
\hline & $11-15$ & $31(21 \%)$ & $26(21 \%)$ & & 1 \\
\hline & $16-20$ & $24(17 \%)$ & $15(12 \%)$ & N/A & 2 \\
\hline & $21-25$ & $22(15 \%)$ & $15(12 \%)$ & & 2 \\
\hline & $26-30$ & $11(8 \%)$ & $13(10 \%)$ & & 1 \\
\hline & More than 30 years & $14(10 \%)$ & $9(7 \%)$ & & 1 \\
\hline \multirow{4}{*}{$\begin{array}{l}\text { School } \\
\text { Level }\end{array}$} & Elementary (G1-6) & $8(6 \%)$ & $10(8 \%)$ & $1(20 \%)$ & 2 \\
\hline & Middle (G7-9) & $54(37 \%)$ & $53(42 \%)$ & $1(20 \%)$ & 5 \\
\hline & High (G10-12) & $76(52 \%)$ & $63(50 \%)$ & 0 & 3 \\
\hline & Others (e.g.Special Ed.) & $7(5 \%)$ & $0(0 \%)$ & $3(60 \%)$ & 0 \\
\hline \multirow[t]{3}{*}{ Region } & Urban & & $99(79 \%)$ & $3(60 \%)$ & 7 \\
\hline & Suburban & N/A & $19(15 \%)$ & $2(40 \%)$ & 3 \\
\hline & Rural & & $8(6 \%)$ & & 0 \\
\hline \multirow[t]{6}{*}{ Subject } & Language Arts & $14(10 \%)$ & $15(12 \%)$ & & 0 \\
\hline & Math & $13(9 \%)$ & $4(3 \%)$ & & 2 \\
\hline & Science/ Technology & $20(14 \%)$ & $17(13 \%)$ & N/A & 2 \\
\hline & Social Studies & $21(14 \%)$ & $16(13 \%)$ & & 1 \\
\hline & English & $42(29 \%)$ & $42(33 \%)$ & & 3 \\
\hline & Elementary/ Others & $35(24 \%)$ & $32(25 \%)$ & & 2 \\
\hline
\end{tabular}

\subsection{Data Collection}

This study consists of three sets of data: online teaching readiness survey, online teaching reflection survey, and interview. An overview of the data collection is shown in Table 2. 
Table 2. An overview of data collection

\begin{tabular}{|c|c|c|c|}
\hline Data type & Metric & Participants & Timeline \\
\hline $\begin{array}{l}\text { Online } \\
\text { teaching } \\
\text { readiness } \\
\text { survey }\end{array}$ & $\begin{array}{l}18 \text { questions, } 3 \text { parts } \\
\text { P1: demographic information. } \\
\text { P2: current understanding and plans for online } \\
\text { learning. } \\
\text { P3: rank and write the support needed }\end{array}$ & 145 teachers & $\begin{array}{l}\text { March-April, } 2020 \text { (two } \\
\text { weeks before the online } \\
\text { teaching transition) }\end{array}$ \\
\hline $\begin{array}{l}\text { Online } \\
\text { teaching } \\
\text { reflection } \\
\text { surveys }\end{array}$ & $\begin{array}{l}31 \text { questions, } 5 \text { parts } \\
\text { P1: demographics } \\
\text { P2: digital equity problems and responses } \\
\text { P3: online teaching experience and } \\
\text { pedagogical approaches } \\
\text { P4: the transition to blended teaching } \\
\text { P5: impact on future teaching and } \\
\text { professional development }\end{array}$ & 137 teachers & $\begin{array}{l}\text { July-August, } 2020 \text { (after } \\
\text { the first semester of } \\
\text { online/blended teaching) }\end{array}$ \\
\hline & $\begin{array}{l}26 \text { questions, } 5 \text { parts } \\
\text { P1: demographics } \\
\text { P2: digital equity problems and responses } \\
\text { P3: online teaching support experience and } \\
\text { pedagogical approaches } \\
\text { P4: the transition to support blended teaching } \\
\text { P5: impact on future administrative support } \\
\text { efforts }\end{array}$ & 5 administ & $\begin{array}{l}\text { July-August, } 2020 \text { (after } \\
\text { the first semester of } \\
\text { online/blended teaching) }\end{array}$ \\
\hline Interviews & $\begin{array}{l}7 \text { questions probing demographics, online } \\
\text { teaching experience, and the experience's } \\
\text { potential impact on their future teaching } \\
\text { practice }\end{array}$ & $\begin{array}{l}10 \text { teachers } \\
1 \text { administrator }\end{array}$ & $\begin{array}{l}\text { July-August, } 2020 \text { (after } \\
\text { the first semester of } \\
\text { online/blended teaching) }\end{array}$ \\
\hline
\end{tabular}

\subsubsection{Online Teaching Readiness Survey}

The survey consisted of 18 questions and was collected two weeks before the transition to online teaching (March-April, 2020) from 145 teachers (see Table 2). Sample questions included: How confident do you feel about conducting classes online?; Are you interested in employing student-centered learning methods such as project-based learning, presentations, discussions, essay assignments, and/or 21C skills-based learning when you teach online?

\subsubsection{Online Teaching Reflection Survey}

Teachers' and administrators' versions of reflection surveys were collected after a semester of online teaching (JulyAugust, 2020) to capture online teaching experiences (see Table 2). While the subset of reflection survey questions on online teaching methods and perceptions aligned to the readiness survey, additional questions regarding blended teaching and its effect on future teaching were unique to the reflection survey. The data was collected shortly after the first semester of online/blended teaching from 137 teachers and eight administrators. Sample questions included: How confident do you feel about conducting classes online?; Did you employ student-centered learning methods such as project-based learning, presentations, discussions, essay assignments, and/or 21C skills-based learning when you taught online?

\subsubsection{Interviews}

The interview consisted of seven questions, and each lasted for 30 minutes. They were conducted both in video conferences and written formats. The interviews were conducted with one district administrator and ten teachers recruited from different subjects, school levels, and teaching experience, as detailed in Table 3. 
Table 3. Pseudonym, Teacher demographics, Student and school leadership, and digital environment

\begin{tabular}{|c|c|c|c|c|c|c|c|}
\hline Name & Gender & Experience & Grade & subject & Position & $\begin{array}{c}\text { Online/ blended } \\
\text { teaching } \\
\text { readiness (prior online } \\
\text { teaching experience and } \\
\text { support received) }\end{array}$ & $\begin{array}{c}\text { Setting \& } \\
\text { Digital Environment }\end{array}$ \\
\hline Julia & $\mathrm{F}$ & $2 \mathrm{Y}$ & N/A & N/A & administrator & Experience: Minimal & $\begin{array}{l}\text { large school district in an urban } \\
\text { city } \\
\text { - not ready for adoption of } \\
\text { online learning }\end{array}$ \\
\hline Brian & M & $22 \mathrm{Y}$ & 7 & Science & head teacher & $\begin{array}{l}\text { Experience: Moderate - } \\
\text { taught with digital } \\
\text { platforms and textbooks } \\
\text { Support: Did not } \\
\text { receive any }\end{array}$ & $\begin{array}{l}\text { School: Urban } \\
\text { - did not provide student digital } \\
\text { literacy education } \\
\text { - did not have a communication } \\
\text { channel with parents } \\
\text { Student: } \\
\text { - only } 3 \text { or } 4 \text { students had } \\
\text { adequate equipment for } \\
\text { interactive-type lessons } \\
\text { - Most students did not receive } \\
\text { parental support }\end{array}$ \\
\hline Jamie & $\mathrm{F}$ & $29 \mathrm{Y}$ & 10 & English & head teacher & \begin{tabular}{lr}
\multicolumn{2}{l}{ Experience: Moderate - } \\
taught with & digital \\
platforms & and \\
technologies & \\
Support: & School \\
teacher training &
\end{tabular} & $\begin{array}{l}\text { School: Urban } \\
\text { - provided } 30 \text { devices and } \\
\text { opened computer labs. } \\
\text { - guided teachers not to use } \\
\text { interactive-type method due to } \\
\text { the students who lacked } \\
\text { Internet access and devices } \\
\text { Student: } \\
\text { - about } 9 \% \text { of the students did } \\
\text { not have access to the Internet } \\
\text { and devices }\end{array}$ \\
\hline Kyle & M & $35 \mathrm{Y}$ & 8 & Math & head teacher & $\begin{array}{l}\text { Experience: Moderate - } \\
\text { taught with digital } \\
\text { platforms } \\
\text { technologies } \\
\text { Support: and } \\
\text { teacher community }\end{array}$ & $\begin{array}{l}\text { School: Urban } \\
\text { - provided prompt support to } \\
\text { marginalized students and } \\
\text { lended devices } \\
\text { Student: } \\
\text { - adequate level of digital } \\
\text { literacy to use LMS fluently }\end{array}$ \\
\hline Penny & $\mathrm{F}$ & $22 \mathrm{Y}$ & $10-11$ & Chemistry & teacher & $\begin{array}{l}\text { Experience: Minimal } \\
\text { Support: School and } \\
\text { district teacher training }\end{array}$ & $\begin{array}{l}\text { School: Urban } \\
\text { systemically supported } \\
\text { devices; however, students } \\
\text { did not request voluntarily } \\
\text { offered a digital literacy self- } \\
\text { help guide book } \\
\text { leaders were supportive in } \\
\text { creating quality blended } \\
\text { learning } \\
\text { Student: } \\
90 \% \text { of the students have } \\
\text { internet access and devices } \\
\text { for remote learning } \\
\text { generally low-motivated }\end{array}$ \\
\hline Sara & $\mathrm{F}$ & $18 \mathrm{Y}$ & 11 & Math & teacher & $\begin{array}{l}\text { Experience: Minimal } \\
\text { Support: School and } \\
\text { district teacher training }\end{array}$ & $\begin{array}{l}\text { School: Urban } \\
\text { - provided teachers tablet PCs } \\
\text { and had smart TV in each } \\
\text { classroom }\end{array}$ \\
\hline
\end{tabular}




\begin{tabular}{|c|c|c|c|c|c|c|c|}
\hline Gen & $\mathrm{F}$ & $5 \mathrm{Y}$ & 7,9 & $\begin{array}{l}\text { Social } \\
\text { Science }\end{array}$ & teacher & $\begin{array}{l}\text { Experience: Extensive } \\
-\quad \text { online/blended } \\
\text { teaching experience } \\
\text { Support: Did not } \\
\text { receive any }\end{array}$ & $\begin{array}{l}\text { School: Suburban } \\
\text { - provided } 60 \text { devices based on } \\
\text { student need-analysis } \\
\text { Students: } \\
\text { - had devices but not adequate } \\
\text { for remote learning } \\
\text { - considerable digital literacy } \\
\text { gap among students }\end{array}$ \\
\hline Helen & $\mathrm{F}$ & $4 \mathrm{Y}$ & 8 & English & teacher & \begin{tabular}{lr}
\multicolumn{2}{c}{ Experience: Moderate - } \\
taught with & digital \\
platforms & and \\
technologies & \\
Support: & School \\
teacher training &
\end{tabular} & $\begin{array}{l}\text { School: Urban } \\
\text {-already had a sufficient } \\
\text { number of devices at school } \\
\text {-systemically supported } \\
\text { devices; however, students did } \\
\text { not request voluntarily } \\
\text { Student: } \\
\text { - had devices at home but had } \\
\text { to share with their siblings or } \\
\text { were not adequate for online } \\
\text { learning } \\
\text {-about } 10 \% \text { of students were } \\
\text { from low-income families } \\
\text {-parents had a low level of } \\
\text { digital literacy; many students } \\
\text { did not receive parental support }\end{array}$ \\
\hline Hana & $\mathrm{F}$ & $10 \mathrm{Y}$ & $8-9$ & Music & teacher & $\begin{array}{l}\text { Experience: Minimal } \\
\text { Support: Did not } \\
\text { receive any }\end{array}$ & $\begin{array}{l}\text { School: Suburban } \\
\text { - provided } 70 \text { devices with } \\
\text { support from the local } \\
\text { government } \\
\text { Student: } \\
\text { - did not have adequate devices } \\
\text { for online learning } \\
\text { - significant digital literacy gap } \\
\text { among students parents }\end{array}$ \\
\hline Tim & $\mathrm{M}$ & $15 \mathrm{Y}$ & 5 & Elementary & teacher & $\begin{array}{l}\text { Experience: Extensive } \\
-\quad \text { online/blended } \\
\text { teaching experience } \\
\text { Support: Did not } \\
\text { receive any }\end{array}$ & $\begin{array}{l}\text { School: Urban } \\
\text {-provided devices for students } \\
\text { in need and supported internet } \\
\text { access } \\
\text { Student: } \\
\text { - parents had a low level of } \\
\text { digital literacy } \\
\text { - an achievement gap between } \\
\text { students with parental support } \\
\text { and those without }\end{array}$ \\
\hline Kate & $\mathrm{F}$ & $20 \mathrm{Y}$ & $4-6$ & Elementary & teacher & $\begin{array}{l}\text { Experience: Minimal } \\
\text { Support: Extramural } \\
\text { teacher community }\end{array}$ & $\begin{array}{l}\text { School: Suburban } \\
\text {-provided devices and internet } \\
\text { access upon request } \\
\text { Student: } \\
\text {-most had their own devices for } \\
\text { online learning }\end{array}$ \\
\hline
\end{tabular}

\subsection{Data Analysis}

For the quantitative data, descriptive analysis was conducted to examine the frequency, percentage, and central tendency of the options. To understand teachers' online teaching confidence, adaptability, and incorporation of 21C skills-based learning across time, an independent $t$-test was used to compare the differences before and after converting to online teaching. Furthermore, a regression analysis was used to understand which factors were related to student-centered online teaching.

For the interviews, we engaged in multiple cycles of coding using the cloud-based qualitative software, Atlas.ti. During the initial round of coding, we sought emergent codes focusing on research questions. Then, the codes were organized and grouped based on the theoretical frameworks, AT and TPACK. Two of the researchers coded synchronously using cloud-based coding software. Thus, disagreements in the codes were discussed in real-time and resolved. 


\section{Results}

The results address the two research questions: how teachers and administrators addressed digital equity problems and how they transitioned to online teaching. For each research question, we present quantitative results to identify an overarching trend followed by the qualitative analysis for in-depth understanding. By presenting quantitative and qualitative data, we aim to validate and expand quantitative results with qualitative data (Creswell \& Plano Clark, 2007).

\subsection{Digital Equity Issues}

Most teachers (96.03\%) and the administrators (87.50\%) experienced digital inequity as illustrated in Figure 3, which shows the percentage of teachers and administrators who selected the different digital inequity issues. More than half of the teachers $(58 \%)$ identified the students' differing levels of digital literacy as a source of digital inequity, while the administrators were concerned about device access (75\%) than the pedagogical issues, such as digital literacy (38\%).

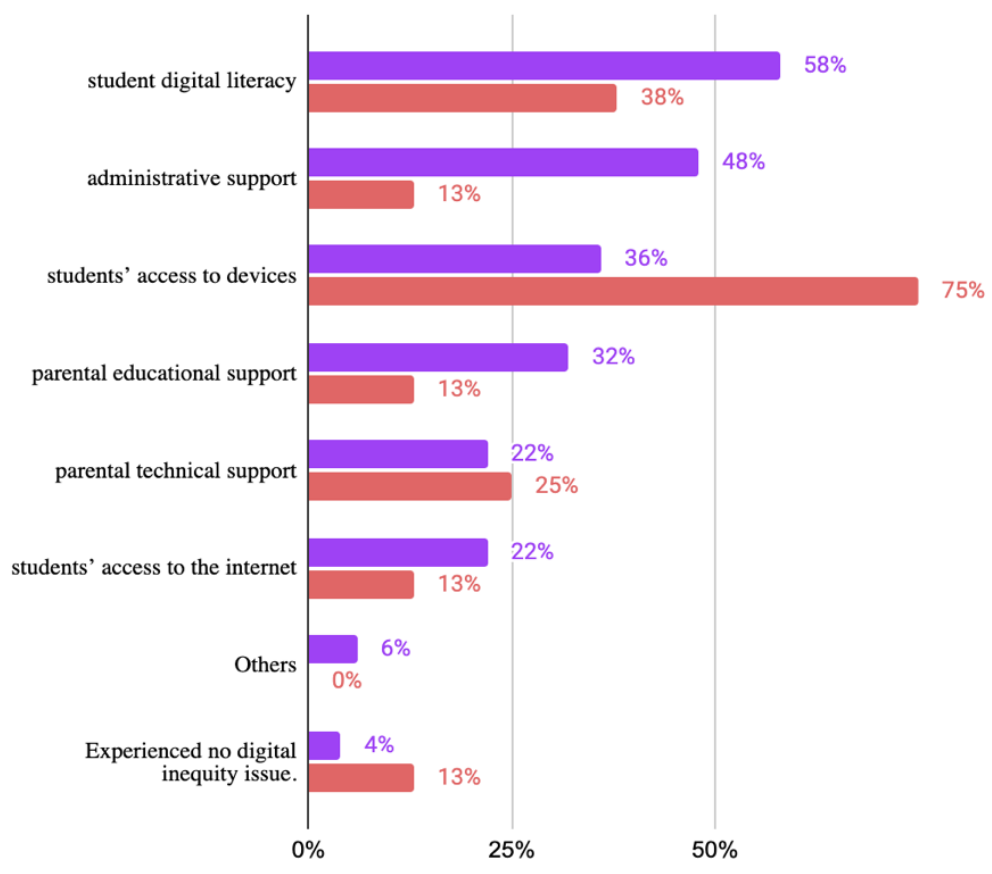

Teachers $(\mathrm{N}=126)$

Administrators $(\mathrm{N}=8)$

Figure 3. Digital Inequities Experienced during Online Teaching

Similarly, most teachers (99.21\%) and administrators (100\%) faced technical and pedagogical challenges during the transition to online teaching. Figure 4 and Figure 5 shows the difficulties teachers and administrators experienced, coded with the TPACK framework (Figure 4) if applicable. Among them, integration of technological pedagogical content knowledge was reported as the most challenging as it required the highest level of synthesis. Among the difficulties that were not coded with TPACK, teachers most commonly expressed their frustration with the complexity and inconsistency of the governmental regulations. Administrators mostly expressed concerns about the lack of support for underachieving students' widened learning gap. 


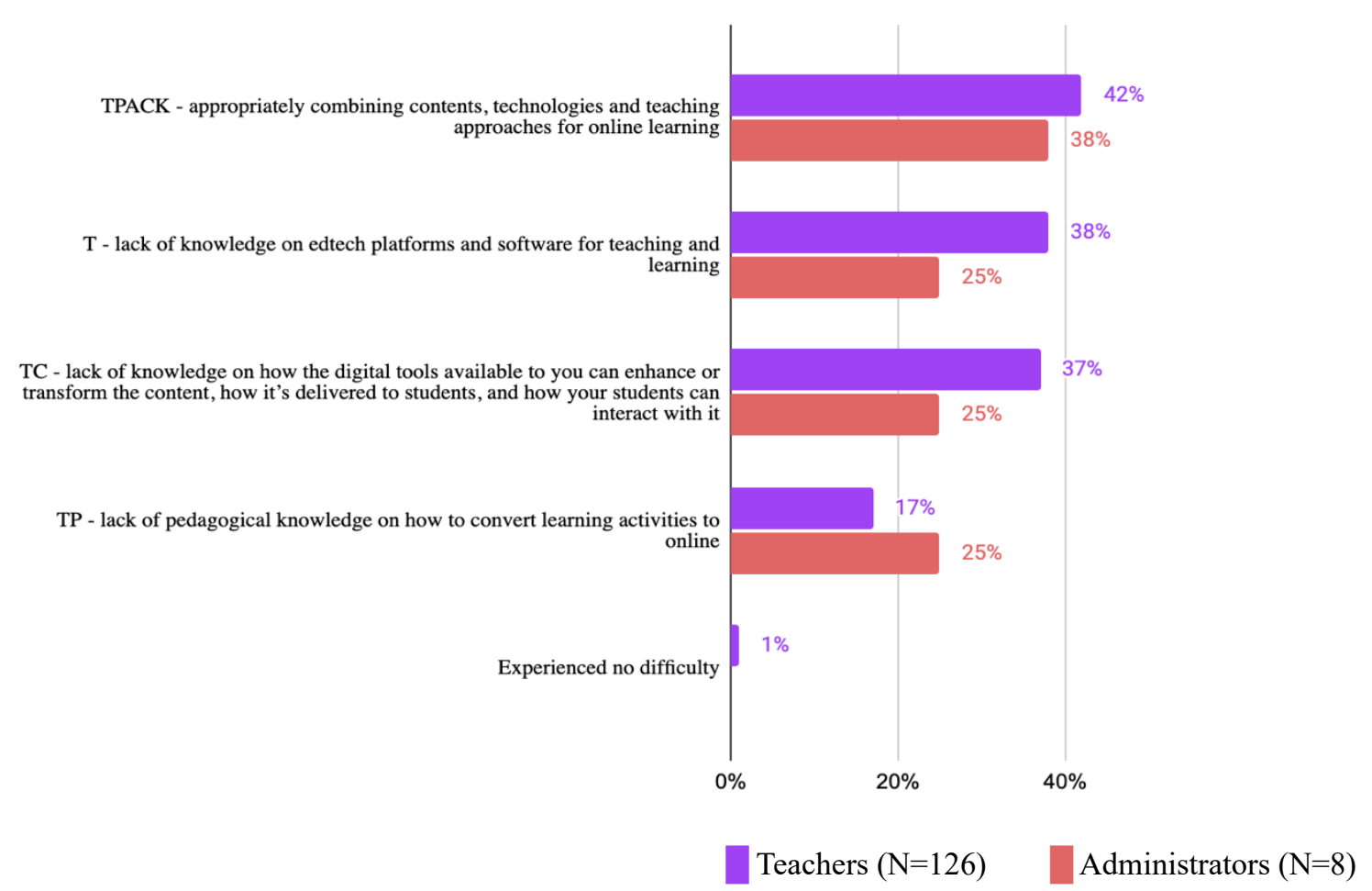

Figure 4. Difficulties Related to TPACK Experienced during Online Teaching

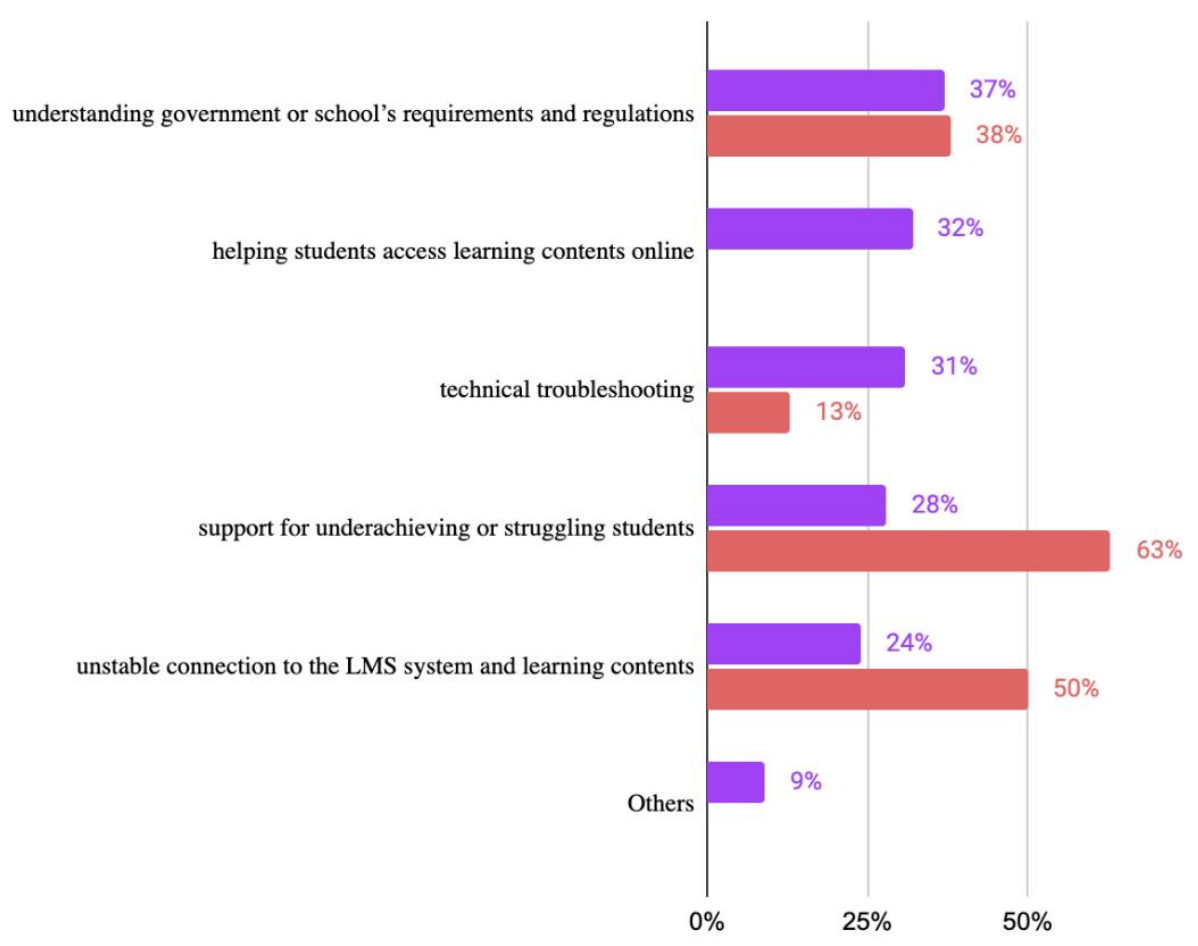

Teachers $(\mathrm{N}=126)$

Administrators $(\mathrm{N}=8)$

Figure 5. Other Difficulties Experienced during Online Teaching

In the interviews, codes related to digital inequity included "achievement gap," "inadequate device for synchronous lessons," and "disparity in parental support and digital literacy." Seven teachers noted that students' achievement gaps widened. While students with self-directed learning skills, parental support, access to private tutoring and appropriate devices successfully executed online learning, marginalized students experienced difficulties without adequate support from guardians or teachers. Particularly, elementary teachers indicated that parental support was essential for young learners due to issues such as online platform sign-up and shorter attention span. Four teachers noted that the parental 
digital literacy gap was another factor exacerbating students' achievement gap. As a result, teachers had to communicate through an excessive number of phone calls to support both parents and students and expressed the need for recruiting teacher assistants for educational and technical support.

While digital inequity issues existed, pedagogical and administrative efforts were made to address the issues. Teachers addressed the achievement gap among students by providing individualized support and feedback. For instance, Jamie and Kyle provided personalized or level-differentiated activities, and they kept track of learning progress using learning analytics. Three teachers collected student and parent surveys to gauge the digital environment and students' learning preferences. Penny set up in-person office hours for underachieving students and provided printing services to reduce accessibility gaps. Teachers advanced their efforts through purposeful lesson planning to maintain engagement. Kyle stated, "when the lesson design is diverse and meaningful, it engages low-motivated students in online learning."

Every interviewee stated that the students' device and Internet access issues were resolved on account of administrative support. Students were able to borrow devices from their schools, and school infrastructure for online education constantly improved. The government and network carriers collaborated to provide data-free access to educational apps. Regardless of accessibility, the quality of devices was not accounted for as some devices were not suitable for synchronous lessons, hindering teachers' deliberate choice of online teaching methods.

\subsection{Transition to Online Teaching}

This section explores the findings based on research questions: (1) teachers' choices and perceptions of online teaching methods; (2) changes in online teaching pedagogies; and (3) perceived impact on future education and professional development.

\subsubsection{Teaching Methods}

Both surveys and the interview asked which of the three online teaching methods provided by the Korean government's guidelines (i.e., task-type, content-type, interactive-type) were employed.

Teaching methods and the perceived effectiveness. The readiness survey asked what online teaching methods the teachers planned to use for their lessons, and the reflection surveys asked what they had used. Most teachers selected multiple lesson types, suggesting they mixed methods. Table 4 shows that the content-type was the method most frequently planned to be used and employed. However, the gap between the chosen methods widened dramatically due to the drop of teachers who employed the interactive-type lessons. Only $27.78 \%$ of the teachers from the reflection survey responded that they employed the interactive-type, which is a stark contrast to the $65.52 \%$ of teachers who had planned to use this method.

Table 4. Number of Teachers who Included Each Online Teaching Method

\begin{tabular}{lcc}
\hline & $\begin{array}{c}\text { Methods Planned to Use } \\
(\mathrm{N}=145)\end{array}$ & $\begin{array}{c}\text { Methods Used } \\
(\mathrm{N}=126)\end{array}$ \\
\hline task-type & $88(60.69 \%)$ & $89(70.63 \%)$ \\
content-type & $96(66.21 \%)$ & $97(76.98 \%)$ \\
interactive-type & $95(65.52 \%)$ & $35(27.78 \%)$
\end{tabular}

For a profound understanding of the methods, teachers were asked to report the pedagogical activities for each type. Figure 6 shows the percentage of teachers who included each activity among those who stated they chose the specified method. In general, the teachers both planned to use and used the activities that were more teacher-centered and closedanswered than student-centered or open-ended. 


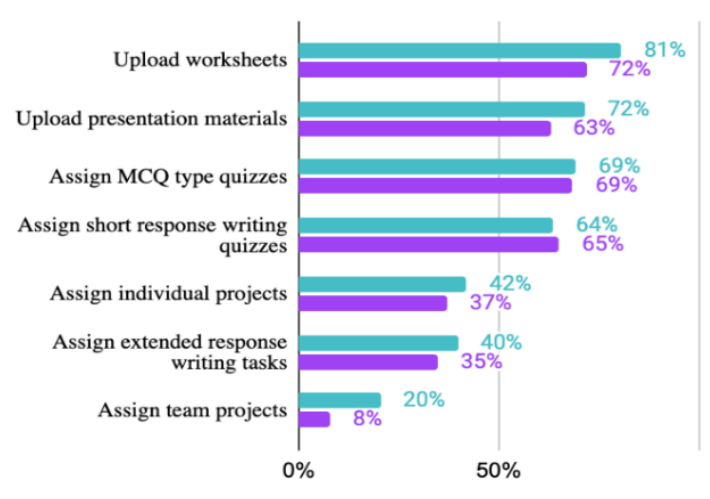

Task-type

readiness $(\mathrm{N}=88) \quad$ reflection $(\mathrm{N}=89)$

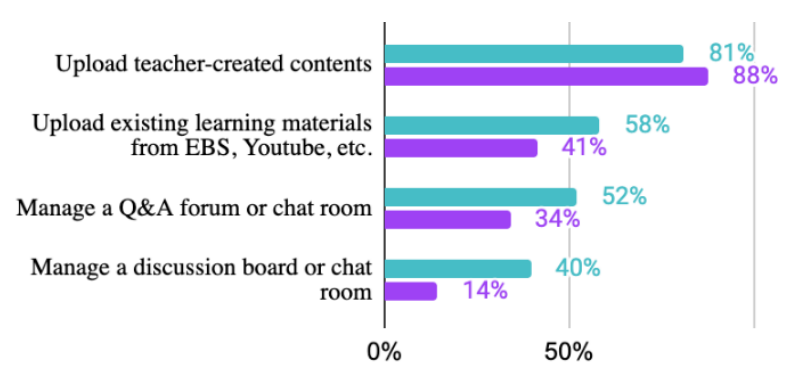

Content-type

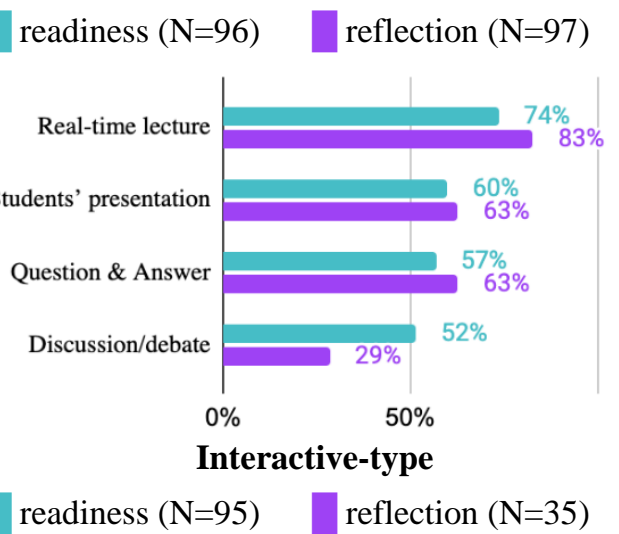

Figure 6. Types of Activities Chosen for Each Method

The reflection survey asked how effective they thought each method was on a scale of 10 , highly effective, to 1 , not effective at all. Table 5 shows that while all three methods were perceived to be somewhat useful; both teachers and administrators thought the interactive-type method was the most effective, though chosen the least.

Table 5. Central Tendency of Effectiveness of Methods

\begin{tabular}{lcccccccccc}
\hline & \multicolumn{3}{c}{ Teachers } & \multicolumn{5}{c}{ Admins } \\
\hline & $N$ & $M$ & $M d n$ & $S D$ & $N$ & $M$ & $M d n$ & $S D$ \\
\hline task-type & 89 & 6.00 & 6.00 & 1.87 & 8 & 5.75 & 6.00 & 1.67 \\
content-type & 97 & 6.34 & 7.00 & 1.76 & 8 & 5.88 & 5.00 & 2.23 \\
interactive-type & 35 & 7.72 & 8.00 & 1.75 & 8 & 7.25 & 7.00 & 1.16
\end{tabular}

Similar trends were observed in the interviews in that eight out of ten employed task-type lessons, all of them employed content-type, and five employed interactive-type. How the teachers conducted each type of lesson are described below.

For the task-type lesson, the frequently identified codes were engagement, diverse assignments, collaboration, feedback, individualization, and lack of assessment. Distinct from the teachers' preferences for teacher-centered tasks in the surveys, the interviews demonstrated that task-type lessons could be student-centered, engaging, and individualized. For instance, Jamie said, "I provided Further Learning optional tasks for students to immerse into their own interests." Kate and Tim actively used online discussion boards or collaboration tools to increase a sense of teacher and classmate presence.

Although the content-type was the most employed method, interviewees perceived it the least effective due to low student engagement and difficulties with feedback. All interviewees created thei content in addition to the government provided EBS materials to better reflect lesson objectives and students' needs. Teachers who initially only employed content-type 
lessons later integrated task-type and interactive-type lessons to promote students' engagement.

The interactive-type was the least employed but perceived the most effective because of student engagement, collaboration, comprehension check, immediate feedback, and rapport-building opportunities. Teachers, however, expressed difficulties in interaction when students turned off their video or muted. Teachers were also concerned about low attendance caused by the digital divide, as described by Hana: "Some students who were consistently absent for the synchronous online lessons said that the Internet was unstable or the computer did not operate." Helen also identified absentee's learning loss. As infrastructure improved, more teachers planned to employ interactive-type methods combined with asynchronous methods.

Underlying factors for method selection. To further investigate what factors might have impacted the online teaching methods selection, the survey asked who decided the means of online teaching (ex. platform, online teaching methods). Figure7 shows that in most cases, the consensus was reached through a task force team consisting of teacher representatives $(44 \%)$ or as a whole group $(25 \%)$.

Teachers $(\mathrm{N}=126)$

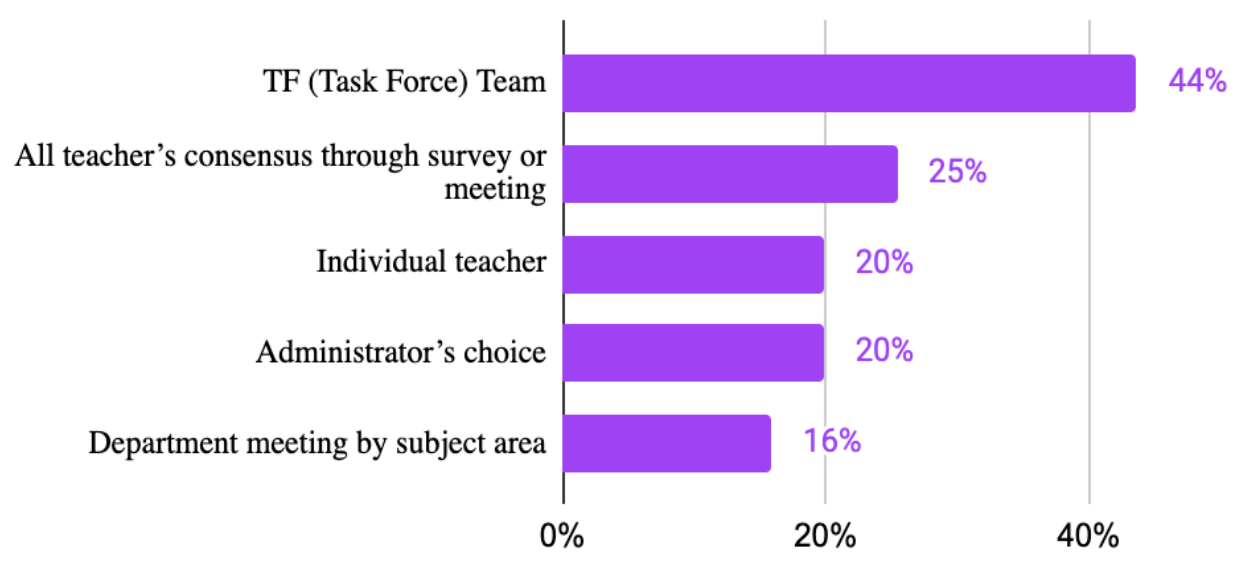

Figure 7. Decision Makers of the Online Teaching Platform/Method

The interview data uncovered the underlying factors to method choices. Teachers who purposefully planned their lessons chose the method according to their teaching objectives and their student-centered mindsets. Others mentioned that they decided without pedagogical considerations due to insufficient preparation time, rigid administrative guidelines on attendance and assessment, and school consensus over individual teachers' preferences. Eight teachers noted that the rigid national assessment guidelines, with undue emphasis on fairness, did not allow performance assessment in content- and task-type lessons, discouraging teachers' deliberate teaching methods selection and students' participation. Also, the unsettled national guidelines were another hindrance to stable lesson planning.

\subsubsection{Changes in Online Teaching Pedagogies}

Perceived changes in readiness, confidence, support, and student-centered teaching methods. To examine how the online teaching pedagogies changed, we compared the teachers' readiness and reflection survey responses through an independent t-test. As Table 6 shows, at the end of the semester, teachers showed higher confidence in online teaching $(\mathrm{t}=7.01, \mathrm{p}<.001)$, felt they received more administrative support $(\mathrm{t}=5.67, \mathrm{p}<.001)$, and felt more competent at tailoring materials suitable to online teaching $(\mathrm{t}=7.01, \mathrm{p}<.001)$ compared to the beginning of the semester. However, teachers showed less willingness to employ student-centered or $21 \mathrm{C}$ skill-based online lessons $(\mathrm{t}=-3.33 \mathrm{p}=.001)$. 
Table 6. Central Tendency of Online Teaching Pedagogy Questions

\begin{tabular}{|c|c|c|c|}
\hline \multirow{3}{*}{ rated from a scale of $1-10$} & \multirow{3}{*}{$\begin{array}{c}\text { Readiness } \\
\text { Teachers } \\
(N=145)\end{array}$} & \multicolumn{2}{|c|}{ Reflection } \\
\hline & & Teachers & Administrators \\
\hline & & $(N=126)$ & $(\mathrm{N}=8)$ \\
\hline \multirow{3}{*}{ How confident do you feel about conducting classes online? } & $M=5.27$ & $M=7.06$ & $M=6.00$ \\
\hline & $M d n=6.00$ & $M d n=7.00$ & $M d n=6.00$ \\
\hline & $S D=2.32$ & $S D=1.79$ & $S D=1.77$ \\
\hline \multirow{3}{*}{$\begin{array}{l}\text { Do you think you are getting/received }{ }^{*} \text { enough support to conduct } \\
\text { your classes online? }\end{array}$} & $M=3.61$ & $M=5.28$ & $M=6.00$ \\
\hline & $M d n=3.00$ & $M d n=5.00$ & $M d n=6.00$ \\
\hline & $S D=2.40$ & $S D=2.47$ & $S D=1.85$ \\
\hline \multirow{3}{*}{$\begin{array}{l}\text { How much do you know about how to properly/How well were you } \\
\text { able to convert your existing learning materials for use in online } \\
\text { classes? }\end{array}$} & $M=5.43$ & $M=7.29$ & $M=5.88$ \\
\hline & $M d n=5.00$ & $M d n=8.00$ & $M d n=5.5$ \\
\hline & $S D=2.31$ & $S D=2.01$ & $S D=1.13$ \\
\hline \multirow{3}{*}{$\begin{array}{l}\text { Are you willing to/Did you employ student-centered teaching } \\
\text { methods and/or } 21 \mathrm{C} \text { skills-based learning when you taught online? }\end{array}$} & $M=6.57$ & $M=5.49$ & $M=5.50$ \\
\hline & $M d n=7.00$ & $M d n=5.50$ & $M d n=5.00$ \\
\hline & $S D=2.49$ & $S D=2.81$ & $S D=0.93$ \\
\hline
\end{tabular}

*Note. The italics represent the difference in the readiness and reflection survey questions.

Given the statistically significant decrease in the preference for student-centered teaching, we further investigated the factors that might have impacted the employment of student-centered lessons by exploring various multiple linear regression models. The choice to deliver student-centered lesson was related to the teachers' online teaching confidence ( $b=0.26, \mathrm{p}=0.001)$, whether they employed interactive-type lessons $(b=0.22, \mathrm{p}=0.008)$, and their ability to tailor materials in online formats $(b=0.18, \mathrm{p}=0.068)$, as shown in the significant multiple linear regression equation $(\mathrm{F}(3,122)=13.701$, $\mathrm{p}<.001$ ), with an $\mathrm{R}^{2}$ of 0.252 .

Similarly, the interviews also demonstrated increased confidence, efficiency, and administrative support. Teachers initially felt challenged integrating their student-centered mindsets into blended teaching aligned with the survey results but gradually implemented student-centered activities as they built a rapport with students, enhanced their TPACK, and reflected on students' feedback. Kate stated that "It was not easy to learn new online tools, but now I have gained technological competency. I am planning to employ more student-centered projects in the upcoming semester."

Julia described how administrative efforts were made and changed over time: "Initially, the bureaucratic system and the administrator's temporary approach to the pandemic hindered institutional support. This view later shifted to a long-term endeavor, and we responded to teachers' needs by providing professional development programs." She was also concerned about teachers' digital literacy gap caused by individual teacher's effort and adaptability differences.

Transition to blended teaching environments. We further examined how teachers transitioned to blended teaching when schools reopened partially. As illustrated in Figure 8, online activities took the role of supporting in-person classes. Providing content knowledge was a common activity employed by more than half of the teachers in both formats. Regarding the perceived impact of online classes on student learning, both the teachers $(M=6.25, N=126)$ and administrators $(M=6.00, N=5)$ reported slight positivity. 


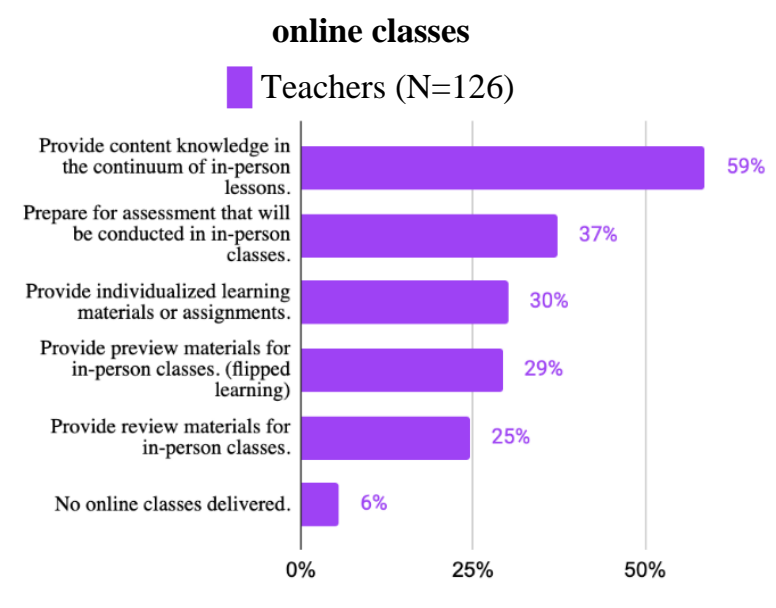

\section{in-person classes}

Teachers $(\mathrm{N}=126)$

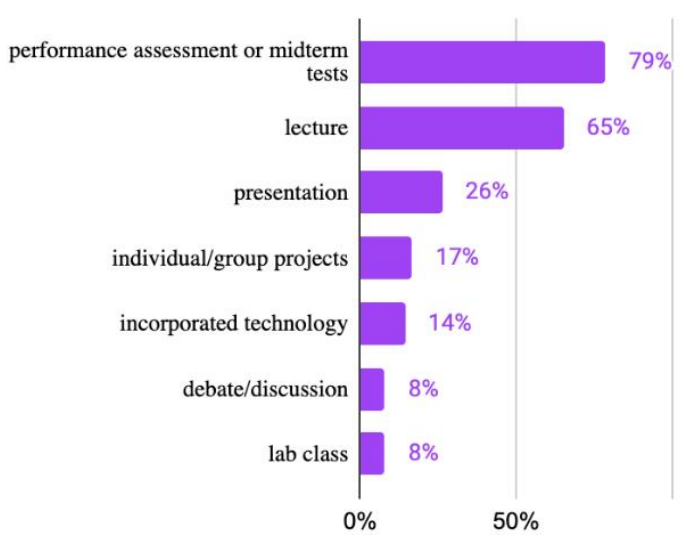

Figure 8. Activities Done in Online and In-person Classes During the Transition Period

In the interviews, teachers mentioned that in-person classes focused on individualized support and students' progress check to narrow the online-learning achievement gap. However, due to strict assessment policies requiring teachers' direct observation for students' performance to ensure fairness, a significant amount of onsite class time was spent on assessment. Moreover, online communication platforms were extended to in-person classes since the social-distancing guides discouraged collaborative activities.

\subsubsection{Perceived Impact on Future Teaching and Professional Development}

To uncover whether the online teaching experience can transcend beyond the pandemic, administrators and teachers were asked to report the perceived impact on their post-COVID teaching. The majority of teachers reported that their enhanced TPACK skills would persist in the post-COVID era as Figure 9 shows. Similarly, administrators reported that they think the TPACK skills will positively impact future teaching.

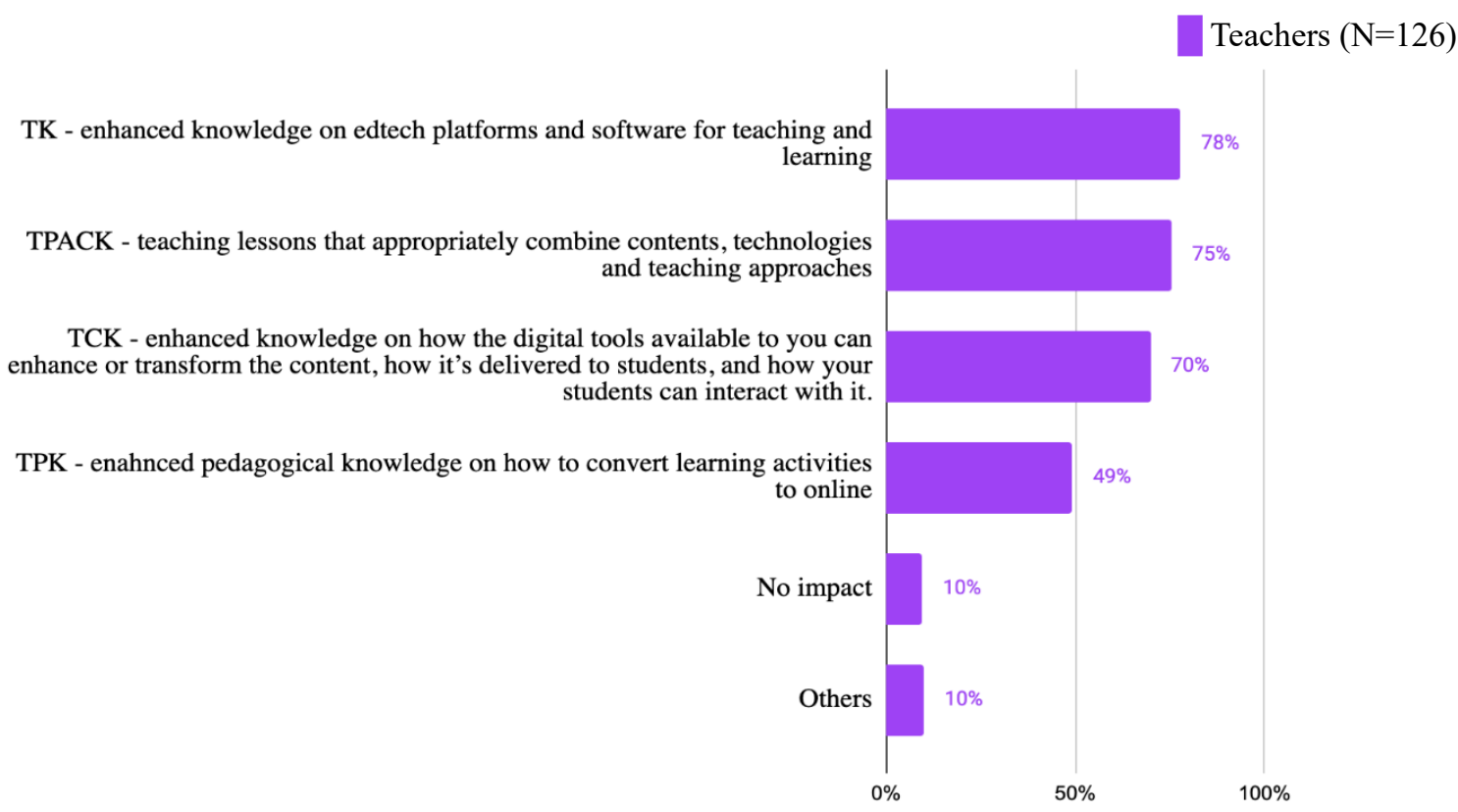

Figure 9. Perceived Impact on Future Teaching

In the interviews, the most frequently mentioned perceived impact was the schools' digital environment improvement. Teachers welcomed schools' digitalization through the new government project, Green Smart Future School (KMoE, 2020b), which will help teachers utilize educational technologies in their post-COVID teaching.

In addition, teachers' enhanced understanding of TPACK and blended teaching, accompanied by shifts in teacher identity and beliefs, were notable. Aligned with the survey data, teachers expressed increased confidence in curriculum redesign. 
Additionally, as LMS platforms became prevalent, managing student portfolios for process-oriented assessment became efficient. Gen elaborated how teachers' increased TPACK and blended teaching skills brought changes in teacher mindsets: "I think the most significant change happened to teachers. Exposure to online teaching allowed teachers to naturally accept positive aspects of technology integration, whereas teaching with technology was considered to be difficult and limited to tech-savvy teachers pre-COVID. Jamie, Kyle, and Julia indicated that online teaching experience allowed them to revisit teaching philosophy and beliefs, resulting in identity transformation into a continuous learner and innovator. Tim, Brian, Kyle, and Kate commented that the teacher communities collaboratively navigated the challenges by sharing lesson materials, Q\&A, and reflections.

Teachers' observation of students' enhanced self-directed learning and digital literacy was another perceived impact. Since online teaching offered flexible and personalized learning experiences, teachers emphasized students' autonomy for future blended teaching. Nevertheless, teachers also acknowledged that struggles with distracted students, a lack of attendance and participation, and student privacy issues should be overcome for sustainable online learning.

Lastly, five teachers envisaged the paradigm shift. They commented that current education systems and policies emphasizing onsite learning, evaluation, competition, and long edtech product procurement processes would hinder future blended teaching practices. To meet the needs of the future generation, they envisioned individualized digital learning with student choice and voice, flexible blended learning beyond time and space, continuous teacher professional development, and providing practical and efficient digital environments.

\section{Discussion}

The study results provided insights into how teachers have dealt with digital equity issues and how they continued to teach resiliently with various blended teaching strategies.

Regarding research question 1, key implications from both surveys and interviews indicated that the achievement gap among students was the utmost digital equity problem. Concerning research question 2, teachers' various strategies to improve their online/blended teaching effectiveness stood out as the main implication. Based on these implications, we integrated our findings to discuss how to 1) improve digital equity by minimizing the achievement gap and 2) maximize learning by considering multiple aspects of online/blended teaching. To understand the multifaceted aspects of the achievement gap and teaching during the pandemic and beyond, the implications from Korean K-12 online education during the COVID-19 are discussed through the lens of activity theory (AT; Engeström, 1999) with teachers as the subject and equitable and effective blended education as the object.

\subsection{Equitable Learning in BT Environment to Minimize the Achievement Gap}

We critically reviewed the multiple facets of digital equity through AT, as shown in Figure 10. The study's key insight showed that the digital equity issue expands to quality teaching issues beyond infrastructural problems. This is because the ultimate goal of digital equity is not only to ensure access to devices but to minimize the learning gap that the transition to online learning may have caused. In this study, the Korean government took rigorous measures to resolve the digital divide; however, the teachers asserted that providing devices and internet connection did not ensure digital equity. 


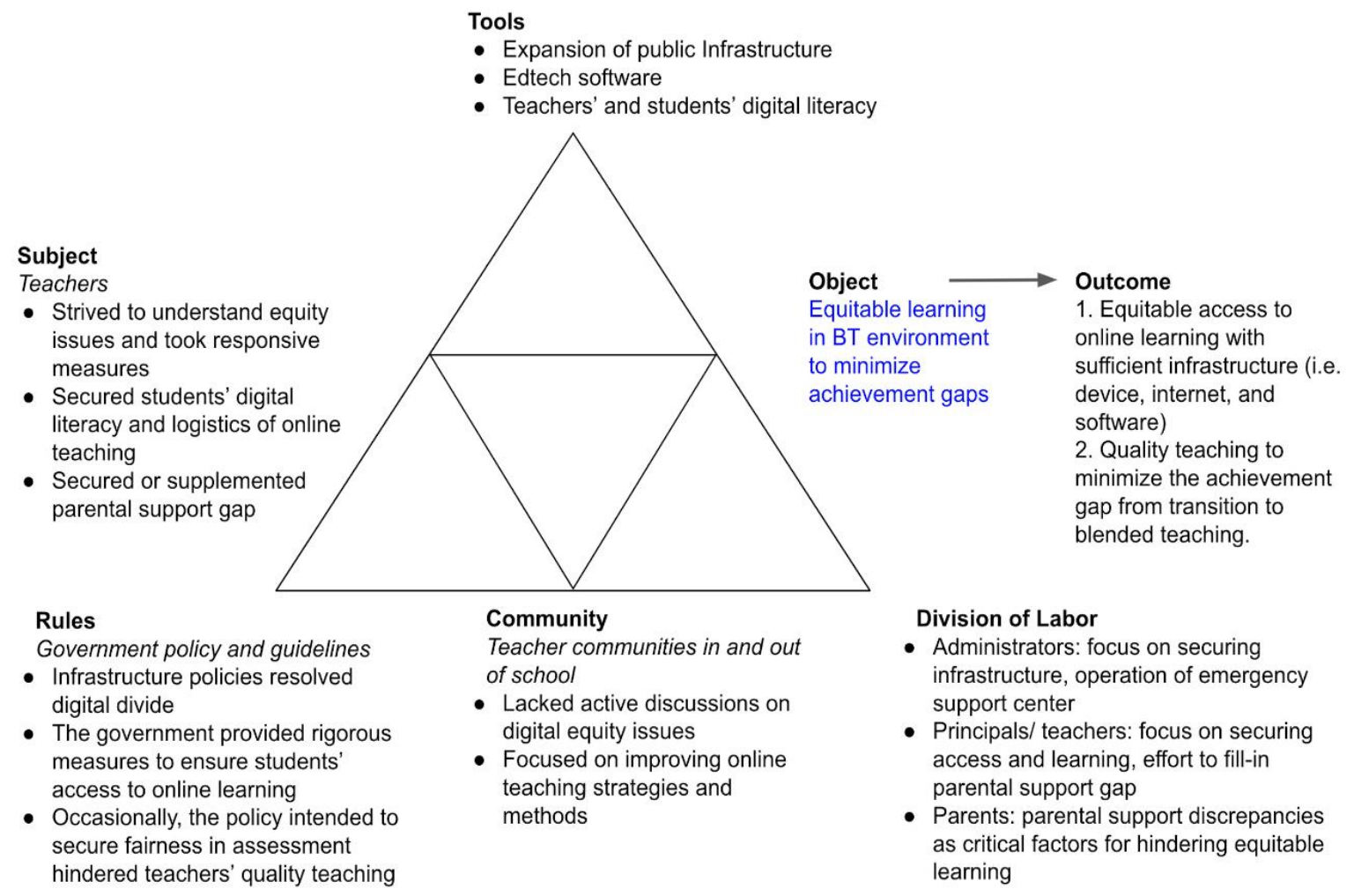

Figure 10. Application of Activity Theory to Analyze Equitable Learning in Blended Teaching Environments

The teachers who are the core subject considered four main factors in securing equity: marginalized students' digital environment, closing the achievement gap, students' digital literacy, and teachers' TPACK and blended teaching competency. The reflection survey data showed differing priorities between teachers and administrators; while administrators focused on securing digital devices for schools, teachers focused on ensuring students' digital literacy, online teaching logistics, and both educational and technical parental support.

As the key implications from the study, we framed the core objective of this activity as equitable learning in blended teaching environments to minimize achievement gaps. Accordingly, the object's final outcome leads to: 1) equitable access to online learning with sufficient infrastructure, and 2) quality teaching to minimize the achievement gap from transition to blended teaching. This is consistent with a survey done by KERIS (Kye et al., 2020); 79\% of the teachers answered that the learning gap has widened since the transition to online learning. As the leading causes, $65 \%$ mentioned the difference in self-directed learning abilities, $14 \%$ as parental support, and $12 \%$ as lack of communication and feedback from teachers. This is not limited to Korea. American students of color were more severely behind in math achievement due to infrastructure and access gaps as well-average math achievement measured December 2020 was $67 \%$ for all students and 59\% for students of color (Dorn et al., 2020). In our study, the insight from the interviews revealed several strategies for reducing the achievement gap: using learning analytic data to pay close attention to marginalized students, designing purposeful lessons to improve participation and engagement, and building a strong rapport with students through both synchronous and asynchronous communication online.

The interview results showed digital equity activity was mediated and influenced by tools including devices, internet bandwidth, online platforms, and teacher and students' digital literacy. Furthermore, the interviewees agreed that the activity was heavily influenced by rules such as the national policy and administrators' guidelines. The government provided rigorous measures such as securing digital devices, collaborating with carriers to enable access to educational apps data-free, and providing a repository of subject-specific videos. However, the policies that intended to prioritize fairness in assessment limited teachers' choices in teaching.

Finally, the division of labor was another key mediating factor for the achievement gap. Regardless of educators' efforts to increase access to online learning and close achievement gaps, parental support discrepancies remained critical. Our study found that younger students' learning was significantly related to parents' educational or technical support and private education access. This implies the need for parents' prerequisite technology training when providing devices for home use (Reich \& Ito, 2017). Our research showed teachers attempted to address the parental gap through excessive efforts; however, this led to teacher burnout. The research findings indicated that the following are needed: digital literacy 
education for parents, close-knit communication channels between school and parents, and a system to gauge and amend parental gaps to avoid teacher burnout. This is aligned with previous research findings that timely communication among school administrators, teachers, parents, and students is the main contributor to successful online learning (Vu et al., 2020). Although many teacher communities were formed to share online teaching strategies and methods, the interviews revealed that the communities lacked active discussions on digital equity.

\subsection{Effective Blended Teaching to Maximize Learning}

The findings revealed that teachers took various strategies to maximize the effectiveness of their blended teaching. Key implications from this study were related to the impact on future teaching, professional development, as well as a paradigm shift in educational philosophy and educational system. With effective blended teaching to maximize learning as objective and teachers as subjects, the implications are explored through the AT framework as in Figure 11.

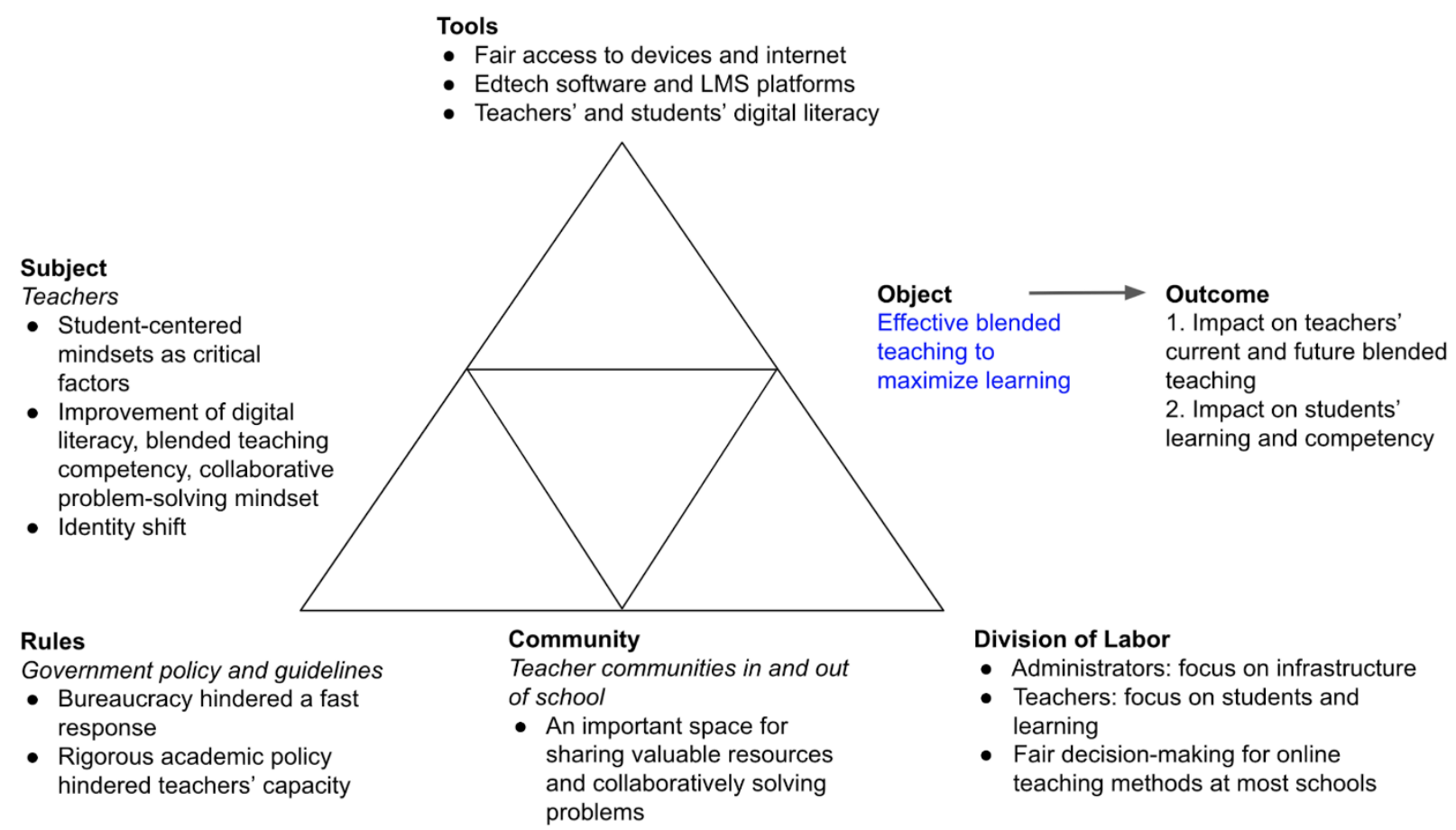

Figure 11. Application of Activity Theory to Investigate Effective Blended Teaching Methods

This study revealed that teachers' student-centered mindsets were critical for effective blended teaching. Although the survey showed discrepancies between teachers' willingness to employ student-centered lessons and their actual implementation, teachers with a robust student-centered mindset integrated these activities into their lessons as their blended teaching competency and environment improved. This implies that setting a student-centered mindset should be prioritized over technology. Furthermore, the online teaching experience fostered teachers' new identities as educators with higher technology integration competency and a stronger collaborative problem-solving mindset.

There were two primary outcomes to effective blended teaching activity: impact on 1) teachers' current and future blended teaching, and 2) students' learning and competency. Beginning with the first outcome, the teachers' choice of online teaching methods were influenced by consideration of the new generation of students' characteristics, assessment, conversion of the current curriculum, and diversifying activities to increase engagement. Based on the challenges and suggestions teachers mentioned in the interview, the following systematic measures can be arranged to promote effective blended learning in public education: national policy aligned with blended teaching field application, institutional level negotiation on copyright issues, expedited digital platform procurement process, and flexible assessment plans. Lastly, the most significant impact found was the paradigm shift in the Korean educational system. The experience of teaching during the pandemic resulted in teachers', administrators', and policymakers' shared understanding of the importance of technology integration and digitization of learning environments, as reflected in the government's new proposal of the Green Smart Future School project (KMoE, 2020b). The second outcome was the impact on students' learning and competency. In the reflection survey, teachers and administrators perceived that online learning positively influenced learning. In the interviews, the teachers indicated students' growth in self-directed learning, digital literacy, individualized learning, and flexible learning. The exacerbated achievement gap, however, was addressed as a critical interference.

The results indicated that blended teaching activity was mediated and influenced by tools including infrastructure, edtech 
software (i.e., LMS, learning assistant software), and teachers' and students' digital literacy. Furthermore, interview results implied the need to address other tool-related issues: edtech product procurement process, copyright, and student privacy.

Furthermore, about $40 \%$ of educators indicated that blended teaching activity was mediated by rules such as government policies and guidelines both positively and negatively. The administrator highlighted that bureaucracy and the absence of government units delayed the response to emergent situations or long-term planning. At the same time, teachers acknowledged the policies to ensure infrastructure and welcomed the government's newly proposed school innovation plans.

The division of labor was another mediating factor for the blended teaching activity. At most schools, online teaching methods were decided democratically, while others who couldn't struggled with limited pedagogical options. This suggests that autonomous decisions are essential to expanding blended teaching in the future. In terms of community, interviews revealed that teacher communities played a critical role in sharing valuable resources and collaboratively solving problems. This implies the importance of supporting teacher communities and a bottom-up approach to expand quality blended teaching in the future.

\subsection{Limitations and Implications for Future Research}

The primary limitation of the analysis relates to the sampling of participants. As the study aimed to do a trend analysis, it included the same general population but not the same individuals in the readiness and reflection surveys, since we used convenient sampling (Mertens, 2015). As the participants across the surveys were not identical, the comparison results should be interpreted with caution. Furthermore, we could not recruit a sufficient number of administrators to participate in the survey and interview, resulting in the low generalizability of administrators' perspectives. The teachers' application and evolution of their TPACK knowledge should also be interpreted with caution. This was due to low awareness of TPACK among the general teacher population; however, this could have been improved by defining TPACK for the respondent to interpret the concept without complication (Mertens, 2015). Lastly, as the study was conducted in the Korean context, the results and implications may be constrained to this specific case study.

For future research, it is important to continue investigating the long-term impact of blended teaching in Korea and globally. Thus, a follow-up study to track how blended teaching was supported, implemented, and evolved in the postCOVID era can be conducted. Furthermore, as this study revealed various factors influencing the quality of blended teaching, further investigation is needed for how each factor can be systematically supported to create ideal blended teaching experiences and environments. Moreover, investigating the role of online and blended teaching in the current education system can provide the direction for the paradigm shift in education. Also, future studies can include both students' and parents' perspectives on blended learning experiences to provide a holistic view. Lastly, future research can include in-depth analysis based on specific populations such as students with exceptional learning needs and marginalized socioeconomic status.

\section{Conclusion}

By investigating how teachers and administrators addressed digital equity problems and converted to online teaching, this study provided a holistic understanding of the transition to online teaching during the first 6-months of the COVID-19 outbreak. We addressed the online teaching methods teachers and administrators chose, how effective they perceived these methods, and how their pedagogies evolved. Furthermore, we examined how this online teaching experience would impact future teaching and the paradigm shift in Korean education. Another main finding indicated that the digital equity issue is related to the achievement gap and quality teaching issues beyond infrastructural problems. Through the application of AT and TPACK, the study provided a holistic understanding of the transition to online teaching by connecting multifaceted aspects of teaching during the pandemic. Hence, as a case study of Korean educators, the findings can serve as a starting point for investigating the transition to online learning for a large public education context on a global scale.

\section{References}

Bury, M. (2012). Activity System. [Image of Activity Theory]. Wikipedia.

https://en.wikipedia.org/wiki/Activity_theory\#/media/File:Activity_system.png

Butler-Henderson, K., Crawford, J., Rudolph, J., Lalani, K., \& Sabu, K. M. (2020). COVID-19 in Higher Education Literature Database (CHELD V1): An open access systematic literature review database with coding rules. Journal of Applied Learning \& Teaching, 3(2), 1-6. https://doi.org/10.37074/jalt.2020.3.2.11

Caffery, L., Martin-Khan, M., \& Wade, V. (2019). Mixed methods for telehealth research. In SAGE mixed methods research (pp. -). SAGE Publications, Inc. https://doi.org/10.4135/9781526498137

Choi, Y. (2020, March 29). Schools busy preparing online teaching-busy testing synchronous, asynchronous, and 
assignment type of class. Kyunghyang News. Retrieved from http://news.khan.co.kr/kh_news/khan_art_view.html?artid=202003292207015\&code=62010

Christensen, C. M., Horn, M. B., \& Staker, H. (2013). Is K-12 blended-learning disruptive? An introduction to the theory of hybrids. Clayton Christensen Institute for Disruptive Innovation. Retrieved from https://files.eric.ed.gov/fulltext/ED566878.pdf

Chung, K., Chang, H., Son, C., Kim, E., Seo, J., Lee, S., Cho, Y., Nam, C., \& Kim, J. (2018). Research for establishing an online education system at secondary level. Korean Educational Development Institute.

Creswell, J., \& Plano Clark, V. (2007). Designing and Conducting Mixed Methods Research. Sage.

Dorn, E., Hancock, B., Sarakatsannis, J., \& Viruleg, E. (2020, Dec. 8). COVID-19 and learning loss-disparities grow and students need help. McKinsey \& Company. Retrieved from: https://www.mckinsey.com/industries/public-andsocial-sector/our-insights/covid-19-and-learning-loss-disparities-grow-and-students-need-help

Educational Broadcasting Station (EBS) Online Class. (2021). About EBS Online Class. https://www.ebsoc.co.kr/onlineclass

Educational Broadcasting Station (EBS). (2021). EBS: Organization history. https://about.ebs.co.kr/kor/organization/history

Engeström, Y. (1999). Activity theory and individual and social transformation. In Y. Engeström, R. Miettinen, \& R.-L. Punamäki (Eds.), Learning in doing: Social, cognitive, and computational perspectives. Perspectives on activity theory (pp. 19-38). Cambridge University Press. https://doi.org/10.1017/CBO9780511812774.003

Jonassen, D. H., \& Rohrer-Murphy, L. (1999). Activity theory as a framework for designing constructivist learning environments. Educational Technology Research and Development, 47(1), 61-79. https://doi.org/10.1007/BF02299477

Kaden, U. (2020). COVID-19 School Closure-Related Changes to the Professional Life of a K-12 Teacher. Education Sciences, 10(6), 165. https://doi.org/10.3390/educsci10060165

Koehler, M., \& Mishra, P. (2009). What is Technological Pedagogical Content Knowledge (TPACK)?. Contemporary Issues in Technology and Teacher Education, 9(1), 60-70. Society for Information Technology \& Teacher Education. Retrieved from https://www.learntechlib.org/primary/p/29544/.

Korean Ministry of Education (KMoE). (2020a). Progress report on 1-month after opening schools online. Korean Ministry of Education.

Korean Ministry of Education (KMoE). (2020b). The Ministry of Education announces plans for Green-Smart Schools of the Future. Korean Ministry of Education.

Korkmaz, G., \& Toraman, Ç. (2020). Are we ready for the post-COVID-19 educational practice? An investigation into what educators think as to online learning. International Journal of Technology in Education and Science, 4(4), 293309. https://doi.org/10.46328/ijtes.v4i4.110

Kuutti, K. (1996). Activity theory as a potential framework for human-computer interaction research. In B. Nardi (Ed.), Context and consciousness: activity theory and human-computer interaction (pp. 17-44). MIT Press.

Kwon, H. (2020, April 7). Online teaching from 9th, if classes taken within 7-days it is considered attendance. News 1. Retrieved from: https:/www.news1.kr/articles/?3898591

Kwon, H. (2021, March 8).74\% of K-12 teachers indicate “EBS Online Class connection is unstable.” News 1. Retrieved from: https://www.news1.kr/articles/?4233990

Kye, B., Kim, H., Lee, Y., Kim, S., Son, J., \& Beak, S. (2020). An analysis on elementary and secondary schools'online education experience - focusing on fundamental statistics. Korea Education and Research Information Service. https://www.keris.or.kr/main/ad/pblcte/selectPblcteETCInfo.do?mi=1142\&pblcteSeq=13356

Lee, J. (2020, March 31). Online school starts' without rehearsal: Concern about lack of class due to lack of equipment. Yonhap News. Retrieved from: https:/www.yna.co.kr/view/AKR20200331086151004?input=1195m

Lee, S., Chung, K., Park, S., Park, J., \& Byun, H. (2017). A study on an analysis of current situations and improvement of online courses for expanding elective course options. Korean Educational Development Institute.

Masonbrink, A., \& Hurley, E. (2020). Advocating for children during the COVID-19 school closures. Pediatrics, e20201440. https://doi.org/10.1542/peds.2020-1440

McAvinia, C. (2016). Online learning and its users: lessons for higher education. Chandos Publishing. 
Mertens, D. M. (2015). Research and evaluation in education and psychology: Integrating diversity with quantitative, qualitative, and mixed methods (4th ed.). Sage publications.

Moore, M. (1997). Theory of transactional distance. In Keegan, D. (Ed.), Theoretical Principles of Distance Education (pp. 22-38). Routledge.

Pullias Center for Higher Education (n.d.). Digital Equity in Education. Retrieved November 4, 2021, from https://pullias.usc.edu/digitalequity/

Reich, J., \& Ito, M. (2017). From good intentions to real outcomes: Equity by design in learning technologies. Digital Media and Learning Research Hub.

Resta, P., \& Laferrière, T. (2015). Digital equity and intercultural education. Education and Information Technologies, 20(4), 743-756. https://doi.org/10.1007/s10639-015-9419-z

Solomon, G. (2002). Digital equity: It's not just about access anymore. Technology \& Learning, 22(9).

Son, C., Chang. H., Kim, E., Kim, S., Lee, E., Jo, I., Chung, K., \& Kim, J. (2019). Research on leveraging learning analytics to design personalized educational support in online learning environment. Korean Educational Development Institute.

Son, J., Ko, Y., Kwon, D., Kim, D., Park, G., Shin, Y., Oh, S., Cha, W., \& Hur, D. (2020). The Online Classes that Teachers are Really Curious about. School Library Journal.

Stein, J., \& Graham, C. R. (2020). Essentials for blended learning: A standards-based guide. Routledge. https://doi.org/10.4324/9781351043991

Tanak, A. (2018). Designing TPACK-based course for preparing student teachers to teach science with technological pedagogical content knowledge. Kasetsart Journal of Social Sciences. https://doi.org/10.1016/j.kjss.2018.07.012

Tashakkori, A., \& Teddlie, C. (2009). Integrating qualitative and quantitative approaches to research. In the SAGE handbook of applied social research methods (2, 283-317). Sage. https://doi.org/10.4135/9781483348858.n9

Teo, T. S., Kim, S. L., \& Jiang, L. (2020). E-learning implementation in South Korea: Integrating effectiveness and legitimacy perspectives. Information Systems Frontiers, 22(2), 511-528. https://doi.org/10.1007/s10796-018-9874-3

Tpack.org. (2012). TPACK. [Image of TPACK]. Tpack.org. http://tpack.org/

Vu, P., Meyer, R., \& Taubenheim, K. (2020). Best practice to teach kindergarteners using remote learning strategies. In R.E. Ferdig., E. Baumgartner, R. Hartshorne, R. Kaplan-Rakowski \& C. Mouza. (Eds), Teaching, Technology, and Teacher Education During the COVID-19 Pandemic: Stories from the Field. (pp. 65-70) Association for the Advancement of Computing in Education (AACE). Retrieved Dec 7, 2020 from https://www.learntechlib.org/p/216903/.

Yoo, S. (2020, May 11). Frustrated in online class, lacking communication and $Q \& A$ sessions. KwangJoo Dream News. Retrieved from: http://www.gjdream.com/v2/news/view.html?news_type=201\&uid=504547

Yoon, E., \& Kim, H. (2016). Exploring the effects of private tutoring, afterschool programs \& EBS participation on academic achievement through the propensity score matching. Korean Journal of Educational Administration, 34, 385-417.

\section{Copyrights}

Copyright for this article is retained by the author(s), with first publication rights granted to the journal.

This is an open-access article distributed under the terms and conditions of the Creative Commons Attribution license which permits unrestricted use, distribution, and reproduction in any medium, provided the original work is properly cited. 